\title{
Communication Strategies for Enhancing Women Participation in Sustainable Agriculture Development in Nigeria: A Critical Review
}

\author{
Mairiga, J*, Momodu, H, Orji, P. O, Halima, M, Roseline, P. O \\ National Agricultural Extension and Research Liaison Services, Ahmadu Bello University, Community Market, Zaira Nigeria, local \\ 810211, Zaria, Nigeria
}

\section{*Corresponding Author}

Mairiga, $J$

\author{
Article History \\ Received: 13.11.2019 \\ Accepted: 20.11 .2019 \\ Published: 22.12 .2019
}

\begin{abstract}
This paper reviewed the communication strategy of Kebbi State Agricultural Development Agency to see how effective it has been in terms of enhancing women's participation in sustainable agricultural development. Descriptive statistics was deployed using both questionnaire and In-depth Interview (IDI) where 372 copies of questionnaire were retrieved and analysed from women farmers in Kebbi state. The paper used to achieve this, literatures on the concept of sustainable agriculture, women's participation in sustainable agricultural development, communication strategies, and barriers to women's participation in sustainable agriculture were reviewed. Findings revealed that both local and conventional strategy were deployed and yielded result in enhancing women's participation as well as send vital message to message. The paper recommended that based on the acceptance of both local and conventional strategies, more efforts by Agricultural agencies and government should be focus on them to further endear women to agriculture in the state and Nigeria at large.
\end{abstract}

Keywords: Sustainable Agriculture, Women Participation, Communication Strategies.

\section{INTRODUCTION}

Communication is an important aspect of humanity that cannot be over emphasised. The need to communicate is part and parcel of man's inert abilities because of his/her needs to interact and pass across messages and information to others around him. Without communication, the world would have amounted to chaos. In fostering communication, there is constant improvement in terms of communication style, techniques and technology. The essence of various forms of communication improvement is to achieve effectiveness. Now the issue of communication is not the key focus, but how effective becomes the paramount consideration. Servaes \& Patchanee [1] opine that communication can actually exist but not effective. The implication of that is obvious, there reason for that such communication cannot be achieved eventually. One of the parameters to judge if a communication is effective is if its gets to the intended audience at the right time, the right place and under the right circumstance that can make them have clear understanding of the message and take action or change behaviour. However, in order to achieve effective communication several government agencies and non-governmental agencies have fashioned out strategies. These strategies rely on the conventional means of communication such as radio, television, newspaper, internet and perhaps local idioms.

In recent times, the issue of communications strategies have become topical because of ineffective deployment of such strategies. For instance, in the agricultural sector despite communication strategies have records low participation of women in Nigeria. In view of this situation. Talabi \& Onasanya [2] state that women constitute $55 \%$ of agricultural labour force in farming processing and trading in Nigeria. As at 2011 the figure was impressive but presently, the figure has dropped drastically due to certain factors such as insecurity (farmer-herdsmen's crises), poverty, ill health, land devaluation and illiteracy. Scholars have opine that the low participation of women in agriculture has communication dimension. Thus this study intends to critically examine the communication strategy that deployed by Kebbi State Agricultural Development Programme to enhance participation of women in agriculture.

Copyright @ 2019: This is an open-access article distributed under the terms of the Creative Commons Attribution license which permits unrestricted use, distribution, and reproduction in any medium for non commercial use (NonCommercial, or CC-BY-NC) provided the original author and source are credited. 


\section{Conceptual Clarifications}

The clarification of the following concepts is imperative to further reveal the gap that this paper intends to fill. Communication Strategies is a combination of two words. The first is communication and the second is strategy. When examined individually, they may mean different things but together, they portray a unique, but crucial issue which this paper examines. Thus, individual as well as collective conceptualization are pertinent. Communication according to Moemeka [3] as an inalienable right of every human being, a right without which man cannot be man. Since communication has been described as a two-step flow, where there is a sender and a receiver therefore, the radio drama should not be seen as a means of distribution but rather a means of communication which is capable not just for transmitting to, but also receiving from the people thereby, allowing the listener not only to hear but also to speak. Furthermore, Servaes \& Patchanee [1] paint a vivid picture of communication as a process whereby information is enclosed in a package and is channeled and imparted by a sender to a receiver via a medium and the receiver then decodes the message and gives the sender a feedback. This infer that the communication is a two way thing and that all forms of communication require a sender, a message, and an intended recipient.

It is also important to note that there are different forms through which communication can take place such as: auditory means, speech, song and tonal voice. These belong to verbal communication. Nonverbal communication include: body language, sign language, paralanguage, touch, eye contact, and media (i.e., pictures, graphics, sound and writing) [3], Importantly, communication affects every part of human endeavours such as commerce, trade, education, health, agriculture, politics, justice, elections and so many too numerous to mention here. But this paper takes a critical look at agriculture which is critical to society.

The word strategy on the second hand literarily means a plan of action intended to accomplish a specific goal. The differentiating factor here is the word "specific" which means that it has to do with a particular area of interest. And this paper looks at the area of agriculture. There is the evidence of action, plan and intention. Plan is a target set, action is the activities that must follow to accomplish the intention and plan. One of activity that can go a long way in achieving a plan is communication. Since communication vary, a suitable one must be identified. In this way, media can be deployed, direct interactions (face to face), and indirect interactions can be used according to the situation or issue at stack. Most often, the media is usually deployed for interventions or communication that is intended to reach a wider number of the population. Radio, television, the internet, newspapers have wider reach and are considered convenient and reliable in recent times. In view of this, several agricultural Authorities in Nigeria (especially state owned) have deployed radio because farmers have access to radio more than other forms of the media. To sum up, communication strategy can be seen as a plan of action that requires the use of various or particular form of communication to accomplish a particular task. Antos [4] categorically stated that strategic communication can achieve a lot in the area of agriculture if consistent and sustainable. This links the issue of sustainable agriculture which according to ... is largely dependent on a workable communication medium (strategy) especially for farmers who reside in the rural areas who also constitute a large population.

\section{Sustainable Agriculture in Nigeria}

According to Derek \& Oyaide [5] sustainable agriculture can be considered as a healthy participation in the sector by youths, women, and men not only in subsistent form but in mechanized form for the production of agricultural goods both for consumption and for exports. Adekanye [6] added that the consistency of agricultural growth of a country makes it status to be regarded as sustainable. Many developed countries of the world have strong agricultural policies as well as communication strategies that create the enabling environments for farmers to achieve consistent growth in agriculture. However, such policies and communication strategies are not vibrant in developing countries including Nigeria [7]. Thus, it becomes imperative to examine the communication strategies deployed by extension agencies in Nigeria of which Kebbi State Agricultural Authority is a part.

Agriculture is the live wire of any nation whether developed or underdeveloped. The difference is that in developed countries there are conscious efforts to boost agricultural production and export the surplus to underdeveloped countries. This can be seen in Nigeria as a case study where it is one of the largest producers of agricultural produce in the world [8]. With arable land, vast land mass, and a good population of people who venture into agriculture. But Nigeria is not self-sufficient in terms of agriculture. Rice importation is high from the Asia and America despite the availability of home grown rice. Nigeria cannot do without importation of foreign rice [8]. Part of the reason for this is the low participation of women in agriculture which forms the crux of this study.

The agricultural sector continues to earn priority attention in growing the economy in view of its previous contributions and huge potential that is worthy of being relied upon for sustained growth and industrialization of the country. Evidence suggests that despite the fact that the country derives about 90 percent of its revenue from oil, the non-oil sector has greater contribution to GDP and records faster growth than the oil sector in recent past. For instance, between 2011 and 2015, Nigeria's economy grew steadily, achieving average annual growth of 4.8 per cent. The non-oil sector fuelled economic growth as it accounted for $112 \%$ of the actual growth experienced during the period - real non-oil GDP increased by N16.2 trillion but oil GDP decreased by N1.8 trillion resulting in an overall increase of N14.4 trillion during the period. While non-oil GDP grew by $6.2 \%$ during this period, oil GDP grew negatively by $4.5 \%$ thus resulting in a lower overall GDP growth of $4.8 \%$. In the non-oil sector, the largest sources of growth during the period were services (53\% of growth; trade $-19 \%$ and other services - $44 \%$ ), agriculture ( $20 \%$ with crop production accounting for $18 \%$ of overall national GDP growth) and manufacturing (21\%). 
Even before the recent past, agriculture had played a key role in driving growth thus further justifying the priority attention being given to it in the economic recovery process. In the 1999 - 2008 period, before the vision 2020 was formulated, agriculture accounted for over $30 \%$ of the growth that occurred in the economy. It is therefore, important to support agriculture to fully realize its growth potentials as way of shoring up the gains in the recent economic recovery efforts. Low productivity is a major characteristic of the agricultural systems (crop, livestock and fishery) in Nigeria. Crop yields in the country are lower than those of most other countries, both in food and cash crop and animal husbandry; and for virtually all the crops, there is an inverse relationship between growth in land area under cultivation and yields. As shown in Figure-3, the yields of grains such as rice, maize, beans and millet remain very low during the period under review. Under the vision 2020, a 3 and 6 fold increase in productivity was targeted by 2015 and 2020 respectively compared to the level in 2009. Applying these to the key staples below, we observe that 2015 yields are far below levels required for overall productivity to have tripled by 2015 and further increase by 2020 .

\section{The Study Area}

The study was conducted in Kebbi State because the extensive agricultural activities and reinvigoration programme to create awareness and enhance participation in agriculture both by the state and federal government. Kebbi was carved out of the old Sokoto State in 1991, and is located within latitudes $100 \_13015^{\prime \prime} \mathrm{N}$ and longitudes 3030 " - 6o E. Kebbi State covers an area of 36 , $129 \mathrm{sq} \mathrm{km}$. It is bounded to the east and north by Sokoto State, to the south by Niger State, to the southeast by Zamfara State, to the west by Benin Republic and to the northwest by Niger Republic (www.kebbistate.org.ng. 2012). The State has an estimated population of about 3,238,628 [9]. Majority of the inhabitants of Kebbi State are peasant farmers who reside in rural settlements particularly along the banks of the Rivers Niger and Rima. It is located in the semi-arid sudano-sahelian ecological zone and experiences serious moisture deficiency in greater part of the year [10]. However, the southern portion of the State falls within a Northern Guinea Savannah ecological zone. The annual rainfall in the State that begins mostly in April and ends in October with highest being recorded in July and August ranges from 400 to $850 \mathrm{~mm}$ increasing both in amount and intensity within the State from the north to the south The State is characterized by high temperatures especially in the months of March, April and May. The annual temperature varies from $210 \mathrm{C}$ to $380 \mathrm{C}$. The soil type found in the State ranges from heavy clay in the fadama areas to loamy, sandy loam and sandy soils in the upland area which supports upland crops like millet, sorghum, rice, cowpea and maize. The fadama crops include tomato, onion, maize, okra, lettuce, carrot, etc. Other occupations in the area include fishing and livestock rearing [11].

\section{Women in Agriculture in Nigeria}

The role of women in agriculture in Nigeria has been assessed by many scholars. Damisa et al., [12] pointed out that various researches conducted on the contribution of women to agricultural development in the country suggest that the women contribution to farm work is as high as between 60 and $90 \%$ of the total farm task performed. The contribution of the women ranges from such tasks as land clearing, land-tilling, planting, weeding, fertilizer/manure application to harvesting, food processing, threshing, winnowing, milling, transportation and marketing as well as the management of livestock. Charles and Willem [13] opined that the importance of the role played by women in agricultural production is such that the widespread failure so far to reach women farmers through formal extension services has major repercussions for national output and food security as well as social justice. Sharon [14] viewed that both women and men play critical roles in agriculture throughout the world, producing, processing and providing the food we eat. Women make up half the rural population and they constitute more than half of the agricultural labour force.

In addition, rural women in particular are responsible for half of the world's food production and produce between 60 and 80 percent of the food in most developing countries. Yet, despite their contribution to global food security, women farmers are frequently underestimated and overlooked in development and communication strategies. Fabiyi, Danladi, Akande, and Mahmood [15] quoting Folasade [16] on 'the role of women in food production' submitted that lack of separate land for women and inadequate contact with extension agents are serious constraints faced by women farmers. Women very rarely own land in Nigeria, despite their heavy involvement in agriculture. Because women generally do not own land or other assets it has traditionally been difficult for women to obtain Bank loans or other forms of credit through the banking system. Land tenure system is largely by inheritance. This lack of title to land prevents women from exercising or improving their expertise in crop production and animal husbandry because of security of tenure. 9365287002

More so, majority of them use low yielding and unimproved planting materials, primitive and labour intensive farm implements, traditional farming practices, which have adversely affected agricultural production. It has been reported that $80 \%$ of the work done on the farm in agricultural activities takes place in rural areas. It is now widely demonstrated that rural women, as well as men, throughout the world are engaged in a range of productive activities essential to household welfare, agricultural productivity and economic growth. Yet women's substantial contribution continues to be under-valued in conventional agricultural and economic analyses and policies, while men's contribution remains the central, often sole focus of attention [15].

Other factors that count against women in participating fully in agricultural development is lack of finance to boost their production (capital/money), this is because many credit associations and export crop market cooperatives limit membership to household heads in many African countries, and Women face greater difficulties than men, particularly with regard to participation in rural cooperatives and access to credit, training and agricultural extension. These difficulties rarely flow from explicitly discriminatory norms, as legislation on these issues is in most cases gender neutral. Rather, they mainly arise from cultural practices and 
stereotypes (e.g. on women's role within the family and on interactions between persons of different sexes) and from socio-economic factors (e.g. as for access to credit, women's higher illiteracy rates, lack of information about available credit programmes, lack of land titles to be offered as collateral, more limited access to formal employment, and exclusion from credit cooperatives) [17]. Onguonu [18] notes that, in Nigeria women do not have access to resources such as finance for the execution of planned projects like their male contemporaries. In some Nigerian communities women are encouraged only to produce food crops for sustaining the family, leaving men in control of the production of cash crops.

Also, education is one of the significant factors affecting the participation of women in agricultural development. Education is an important factor that helps development to be realized. The purpose of education (formal and informal) is to communicate accumulated wisdom and knowledge from one generation to the next. Secondly, education enhances active participation in innovation and the development of new knowledge. Ani et al., [19] argue that education enhances the ability to derive, decode and evaluate useful information for agricultural production. The Food and Agricultural Organization/ United Nations Educational, Scientific and Cultural Organization (FAO/UNESCO) note that:

Better education and training have become essential for sustainable development and for rural economy to survive and lack of education and training has been identified as a key barrier to women's advancement in the society [20].

In sub-Saharan Africa, agriculture accounts for approximately $21 \%$ of the continent's GDP and women contribute $60-80 \%$ of the labour used to produce food. Estimate of women's contribution to the production of food crops range from $30 \%$ in the Sudan to $80 \%$ in the Congo, while their proportion of the economically active labour force in agriculture ranges from $48 \%$ in Burkina Faso to $73 \%$ in the Congo and $80 \%$ in the traditional sector in Sudan. The solution to overcome poverty, hunger and chronic food shortage in Africa, the leaders would need to focus on economic empowerment of the women, especially on the rural women. Rural women do not have equitable access to land and agricultural resources. They have low involvement in development activities and have low decisionmaking power. Their labour and contribution to the agricultural sector is invisible because of the gender division of labour in the society [21].

\section{Extension Service and Communication Strategies}

Extension service involves proactive and systematic communication of innovation to influence human behaviour in the design of agriculture and self-reliant projects and their objectivity [22]. Extension service is a medium through which new innovations on agriculture is passed to the farmer through the extension workers like the institutes of agriculture. Extension service is focused on bringing about rural development. Extension service is the rendering of assistance to farmers to help them identify and analyze their production problems and to become aware of the opportunity for involvement [23].

Extension service is a deliberate and systematic attempt of transferring knowledge and insight to someone in such a way that the person is able take decisions for the betterment of his/her wellbeing. It therefore means that extension is a conscious use of communication of information to help people form sound options and make good decision, it is all about developing the farmers' views and interest in order for them to live a meaningful life. Extension communication is a process whereby two or more people exchange ideas, facts, feelings, thoughts or impressions in manner that each has a common understanding of the actual meaning, intent and use a given message. It is important for communication to be a two way affairs and vital and relevant information must be disseminated to achieve a success.

The practice of extension communication is a diffusion of innovations process, from government or a commercial firm to farms and farmer training centre, otherwise called a simple technology transfer. This is fairly mechanical process and was soon found to be highly defiant, unprogressive and insensitive to the communication audience, or the people who are the real change agents [24]. The method is anchored on persuasion and education. Among the old paradigms of development communication, especially the mass-mediated messages were mainly seen as a means of winning hearts and minds' to the capitalist way of life. However, as time went by, there was need to evolve a more participatory approach to communication in order to sustain agriculture especially in agriculture in the rural communities.

According to Soola [24], the Extension Communication Strategies is meant for training and characterized by regular and continuous training of extension agents and visits of farmers usually on a fortnight basis. It also involves demonstration whereby emphasis is on macro-demonstrations which were used to conduct group meetings and field days. Furthermore, it encourages the use of subject Matter Specialist (SMS) - This involved the use of experts in various fields e.g. agronomists, animal scientists, etc, to teach farmers on the use of particular technology or innovation. One aspect that Soola [24] emphasized is On-Farm Adaptive Research (OFAR) which is a multi-disciplinary team saddled with the duties of planning, monitoring and evaluation of OFAR trials. In view of this, there have been repeated calls for more effective communication strategies to increase women farmers' access to agricultural education and adequate information for proper empowerment. No doubt, this has evolved out of many controversial issues surrounding women in agriculture and the impending dangers it poses to food productions in Nigeria. 
To generate data for this paper, questionnaire was deployed and Inept Interview (IDI). A total of 384 copies of the questionnaire were distributed to farmers in various communities in Kebbi State and 372 copies were returned and analysed as shown below.

Table-1: The Communication Strategies Deployed by Kebbi State Agricultural Development Agency to facilitate Women's Participation in Agriculture

\begin{tabular}{|c|c|c|c|c|c|c|}
\hline \multirow[t]{2}{*}{ S/N } & \multirow[t]{2}{*}{ Communication Strategies } & \multicolumn{4}{|c|}{ Degree of Agreement } & \multirow{2}{*}{$\begin{array}{l}\text { Total } \\
(\%)\end{array}$} \\
\hline & & $\begin{array}{l}\text { Strongly Agree } \\
(\%)\end{array}$ & $\begin{array}{l}\text { Agree } \\
(\%)\end{array}$ & $\begin{array}{l}\text { Disagree } \\
(\%)\end{array}$ & $\begin{array}{l}\text { Strongly } \\
\text { Disagree (\%) }\end{array}$ & \\
\hline 1 & Radio & $101(27.1)$ & $\begin{array}{l}142 \\
(38.9)\end{array}$ & $69(18.5)$ & $60(16)$. & $372(100.0)$ \\
\hline 2 & Television. & $46(12.3)$ & $60(18.5)$ & $\begin{array}{l}121 \\
(32.5)\end{array}$ & $145(38.9)$ & $372(100.0)$ \\
\hline 3. & Community Dialogue & $60(18.5)$ & $52(13.9)$ & $\begin{array}{l}120 \\
(32.2)\end{array}$ & $140(40.3)$ & $372(100.0)$ \\
\hline 4. & $\begin{array}{l}\text { Educational Instructional Communication (EIC) } \\
\text { Materials like Posters, Fliers, Billboards, etc.) }\end{array}$ & $25(6.7)$ & $30(8.0)$ & $\begin{array}{l}167 \\
(44.8)\end{array}$ & $150(40.3)$ & $372(100.0)$ \\
\hline 5. & Women Group Meetings & $\begin{array}{l}89 \\
(23.9)\end{array}$ & $\begin{array}{l}59 \\
(15.8)\end{array}$ & $\begin{array}{l}102 \\
(27.4)\end{array}$ & $\begin{array}{l}122 \\
(32.7)\end{array}$ & $372(100.0)$ \\
\hline 6. & Local Communication Channels & $94(25.2)$ & $\begin{array}{l}102 \\
(27.4)\end{array}$ & $91(24.4)$ & $85(22.8)$ & $372(100.0)$ \\
\hline
\end{tabular}

The table above shows the communication strategies deployed by KARDA to facilitate women's participation in agricultural. Respondents gave $66.0 \%$ to radio, $71.4 \%$ rejected television, $72.5 \%$ also rejected the use of community dialogue, $85.1 \%$ further rejected the use of educational instructional communication (EIC), and $52.6 \%$ accepted the use of local communication channels. In support of radio as a communication strategy deployed by KARDA, Mr. Abdulahi Ahmed, an extension officer state that:

We have deployed radio extensively to bring about information to women famers. We have programmes on farming. Television is a bit of luxury to women here, but when it becomes absolutely necessary, we shall use it for sensitization purposes on a larger scale. The use of flies and handbills is not new to people in this community. When we have programmes and visitations, we ensure to go with educational materials are carried along to keep reminding women long after we had gone.

From the interpretation, it becomes obvious that the use of radio and local communication are the two main communication strategies that KARDA deploys in facilitating the participation of women in agriculture in Ricwu community.

To corroborate the statement above, Hajara Musa a farmer added that:

Most of the sensitive information on agriculture comes to us through the radio. This is because every farmer has radio and even at the remote location in the farm we can still get access to vital information. This is not to say that KARDA has not been using other medium of communication to reach out to us but I think that radio is one of the most effective of all.

This is to further revalidate the fact that radio is easy to maintain, cheap to acquire and does not require electricity to operate. The wide area coverage of the radio signal is another advantage that extension agencies can take advantage of especially in the area of agriculture. However, local medium of communication was considered effective going by the table above. With $52.6 \%$ of the respondents who accepted local communication medium as one of the effective medium used by KARDA, it can be inferred that women value related communication strategies that make use of their local media to communicate. According to Mariam Abdulahi in an In-depth Interview

We women are rural and we have a way of understanding our local media more. This is because we have used these media right from the beginning. As a matter of fact we were introduced to them by our forebears and it has not failed us since. So it is important that agricultural agencies of government should try and adapt them when they want to pass across vital information to us.

\section{CONCLUSION}

It has been established that communication strategy is a crucial aspect of the ongoing campaign to enhance women participation in agriculture. It is also obvious that KSAA deployed communication strategy which is hinged on both local and conventional bases. To a large extent, both strategy have yielded result in enhancing women's participation as well as send vital message to message. However, it important to note that radio and local communication mediums were considered most viable and capable of instigating sustainable growth in terms of women's participation in agriculture in Kebbi state. Based on the acceptance of both local and conventional strategies, it is recommended that more efforts should be placed on them to further endear women to agriculture. 


\section{REFERENCES}

1. Servaes, J., \& Patchanee, M. (2004). Communication and Sustainable Development: background Paper of the IX UN Roundtable on Communication for Development (Rome FAO - in Press).

2. Talabi, S. O., \& Onasanya, O. (2011). Nigeria Agriculture- Introduction. Retrieved on 24/11/2011 (http: //www.onlinednigeria.com/inks/agricadv).

3. Moemeka, A. (2002). Communication and Development. Jedidia Publishers.

4. Antos, G. (2011). Handbook of Interpersonal Communication. The Hague: The Netherlands: Mouton De Gruyter.

5. Derek, R., \& Oyaide. (1986). Impact of Agricultural Development Project (ADPs). Journal of Federal Development, $1(2), 16$.

6. Adekanye, T. O. (1981). African Women in Agriculture Problems and Policy for Development. Preserve African (France), 141(1):7-14.

7. Agbamu, J. U. (2006). Essentials of Agricultural Communication in Nigeria. Malthouse press limited.

8. Odachi, G. N. (2011). Nigeria's Agriculture and Food Security Challenges: ICT Solution. Journal of Research and Development, 3(1)

9. National Population Commission. (2006). National population census, 2006. National Population Commission.

10. Singh, S. N., Fletcher, R. D., Fisher, S. G., Singh, B. N., Lewis, H. D., Deedwania, P. C., ... \& Lazzeri, D. (1995). Amiodarone in patients with congestive heart failure and asymptomatic ventricular arrhythmia. New England Journal of Medicine, 333(2), 77-82.

11. Karda, I. W., \& Spudiati, S. (1997). Relative Palatability By Sheep And Goats Of Oven-dried Calliandra, Albizia, Gliricidia, And Leucaena Leaves. Majalah IImiah Peternakan, 9(2).

12. Damisa, M. A., \& Yohanna, M. (2007). Role of rural women in farm management decision making process: Ordered probit analysis. World Journal of Agricultural Sciences, 3(4), 543-546.

13. Williams, C. A., Dagli, A., \& Battaglia, A. (2008). Genetic disorders associated with macrocephaly. American journal of medical genetics Part A, 146(15), 2023-2037.

14. Labov, W., Ash, S., \& Boberg, C. (2008). The atlas of North American English: Phonetics, phonology and sound change. Walter de Gruyter.

15. Fabiyi, E. F., Danladi, B. B., Akande, K. E., \& Mahmood, Y. (2007). Role of women in agricultural development and their constraints: a case study of Biliri Local Government Area, Gombe State, Nigeria. Pakistan journal of Nutrition, 6(6), 676-680.

16. Folasade, K. F. (1991). The Roles of women in food production in Oyo LGA of Ondo State. An unpublished B. Sc Thesis, Department of Agricultural Extension and Rural Sociology, Obafemi Awolowo University lle-lfe, Nigeria.

17. Elinder, L. S. (2005). Obesity, hunger, and agriculture: the damaging role of subsidies. Bmj, 331(7528), 1333-1336.

18. Onguonu, C. N. (2010). Women and socio-economic development in the local government system in Nigeria.

19. Al Ani, M. N. (2004). Evaluation of some prepared solutions from some medical plants and chemicals on. Pseudomonas aerugenosa.

20. UNESCO, U. (2012). World Water Development Report 4-Managing Water under Uncertainty and Risk.

21. Barker, G. (1996). Farming the Desert: Synthesis (Vol. 1). Unesco.

22. Patel, D. K. (2009). Morphology and medicinal values of a wildly grown medicinal and aromatic herb Hyptis suaveolens (L.) Poit.

23. Adams, D. O., \& Dean, J. H. (1982). Analysis of macrophage activation and biological response modifier effects by use of objective markers to characterize the stages of activation. In NK Cells and Other Natural Effector Cells (pp. 511-518). Academic Press.

24. Soola, E. O. (2003). Development communication: The past, the present and the future. Communicating for development purposes, 9-28. 